\title{
Review
}

\section{Anti-Cancer Drug Screening with Microfluidic Technology}

\author{
Mojdeh Monjezi ${ }^{1}$ (D), Milad Rismanian ${ }^{1}$, Hamidreza Jamaati ${ }^{1}$ and Navid Kashaninejad ${ }^{2, *}$ (D) \\ 1 Chronic Respiratory Diseases Research Center (CRDRC), National Research Institute of Tuberculosis and \\ Lung Diseases (NRITLD), Shahid Beheshti University of Medical Sciences, P.O. Box 19575/154, \\ Tehran 1956944413, Iran; mj.monjezi@gmail.com (M.M.); miladrismanian@gmail.com (M.R.); \\ hamidjammati@hotmail.com (H.J.) \\ 2 Queensland Micro-and Nanotechnology Centre (QMNC), Nathan Campus, Griffith University, \\ Brisbane, QLD 4111, Australia \\ * Correspondence: n.kashaninejad@griffith.edu.au; Tel.: +61-7-3735-5391
}

Citation: Monjezi, M.; Rismanian, M.; Jamaati, H.; Kashaninejad, N. Anti-Cancer Drug Screening with Microfluidic Technology. Appl. Sci. 2021, 11, 9418. https://doi.org/ 10.3390/app11209418

Academic Editor: Richard Yongqing $\mathrm{Fu}$

Received: 15 September 2021

Accepted: 9 October 2021

Published: 11 October 2021

Publisher's Note: MDPI stays neutral with regard to jurisdictional claims in published maps and institutional affiliations.

Copyright: (c) 2021 by the authors. Licensee MDPI, Basel, Switzerland. This article is an open access article distributed under the terms and conditions of the Creative Commons Attribution (CC BY) license (https:// creativecommons.org/licenses/by/ $4.0 /)$.

\begin{abstract}
The up-and-coming microfluidic technology is the most promising platform for designing anti-cancer drugs and new point-of-care diagnostics. Compared to conventional drug screening methods based on Petri dishes and animal studies, drug delivery in microfluidic systems has many advantages. For instance, these platforms offer high-throughput drug screening, require a small number of samples, provide an in vivo-like microenvironment for cells, and eliminate ethical issues associated with animal studies. Multiple cell cultures in microfluidic chips could better mimic the 3D tumor environment using low reagents consumption. The clinical experiments have shown that combinatorial drug treatments have a better therapeutic effect than monodrug therapy. Many attempts have been made in this field in the last decade. This review highlights the applications of microfluidic chips in anti-cancer drug screening and systematically categorizes these systems as a function of sample size and combination of drug screening. Finally, it provides a perspective on the future of the clinical applications of microfluidic systems for anti-cancer drug development.
\end{abstract}

Keywords: drug screening; monodrug or combinatorial drug screening; anti-cancer

\section{Introduction}

Microfluidic technology has various potential applications in cancer research, including drug screening, drug discovery, immunotherapy, and clinical oncology [1,2]. In this review, we focus on the recent advances in cancer drug screening using microfluidic technology.

The 2D cell culture cannot mimic the native 3D physiological environment and cellular response in vivo [3]. On the other side, animal models cannot detect the side effects of drugs well because of the biological differences between humans and animals. There is evidence that in vitro 3D tumor models can improve the preclinical predictions for cancer therapies due to their physiological relevance [4]. Hence, 3D cell tumor models are increasingly interesting to study the cell response to various stimuli. However, there are concerns with the reproducibility of the results achieved by $3 \mathrm{D}$ models due to large variabilities among these models [5]. So, these models still do not meet the required standards for preclinical trials. The 3D tumor models can be classified into scaffold-free systems, scaffold-based systems, hydrogel-based models, bioreactor-based models, microcarrier-based models, cancer-on-a-chip, and bioprinted models [6-8]. Organoids and patient-derived tumor xenografts are advanced strategies desriable for mimicking 3D tumor architecture and the in vivo microenvironment, respectively. Despite the great efforts in drug screening on 3D models, enormous challenges still exist for personalized drug screening for clinical trials [9]. The establishment of standardized methodologies can bring these 3D models to preclinical tests $[6,10]$. More details on the tumor microenvironment in terms of its physical, chemical, and biological composition can be obtained from the excellent review paper by [10]. 
Different microfluidics technologies in cell-based high-throughput drug screening, including perfusion flow, droplet, and microarray modes are reviewed by [11]. Microfluidic concentration gradient generators, cell co-culture models, organ-on-chips, and combinations of microfluidic with other high-throughput systems can be found in the detailed review by [12].

Combinatorial drug treatment has shown its superiority over monodrug therapy for many diseases, especially for cancers, due to intra-tumor heterogeneity [13,14]. Although different anti-cancer drugs have been developed for cancer, mono-drug treatments typically fail in the war against cancer [15]. Compared to mono-drugs, drug combinations can simultaneously inhibit multiple excessive pathways of tumor cells and have better efficacy $[16,17]$. In this context, microfluidics could overcome the expensive and time-consuming process of combinatorial drug screening with high-throughput screening (HTS) of more compound candidates [18]. Microfluidics is a promising science and technology that can be used in various industrial [19] as well as biological and biomedical applications, including cell culture [20], cell separation [21], cryopreservation [22], and drug delivery [23].

The recent progress in microfluidic platforms for anti-cancer drug screening is wellreviewed in [24], in which current microfluidic devices are categorized as 2D, 3D, and droplet-based. Moreover, new research to address drug resistance, combinatorial drug therapy, cancer metastasis, and cancer heterogeneity is also discussed. Valente et al. also reviewed anti-cancer drug development with the application of microfluidic technology with a focus on the modeling of the tumor microenvironment, high-throughput assays, and microfluidic-integrated biosensors [25].

Since the sample size is different for each type of cancer, the developed microfluidic systems should be tuned based on the sample size [26]. For example, liquid, tissue, or surgical biopsy can be used to capture the circulating tumor cells (CTCs) $[27,28]$, a small piece of cancer tissue or a large sample of cancer tissue, respectively. This review guides the reader to the appropriate microfluidic drug screening chips developed for their available sample size. Since different modes of drug testing (mono or combinatorial) could be desired, this study classifies the presented microfluidics into three categories based on sample size and combinatorial or monodrugs for drug screening applications. These categories include monodrug screening on a microscale sample, monodrug screening on a macroscale sample, and combinatorial drug screening on a microscale sample.

The main goal of the first class (mono drug screening on a microscale sample) is to examine the effect of a single drug on a microscale sample. For instance, in biological applications, micro samples (i.e., single cells or multicellular aggregates) are exposed to specific drug doses. As such, this class is not suitable to evaluate cancer tissues for ex vivo applications. The second class (mono drug screening on a macroscale sample) is designed to eliminate the limitation of sample size associated with the first class. So, the drug gradient is generated in a macroscale sample (e.g., microdissected tissues). However, these two classes of microfluidics cannot evaluate the combination therapy. Accordingly, the third type of microfluidic platform has been designed to test combinations of anti-cancer drugs on microscale samples. However, there is a lack of combinatorial drug screening on macroscale samples. Furthermore, all mentioned classes can only generate and test countable concentrations due to the discrete concentration gradient generator.

Therefore, a novel class of microfluidic systems to simultaneously deliver continuous gradients of two drugs on a macroscale sample to address the aforementioned limitations is of high importance. In the following sections, the pros and cons of each of these classes will be thoroughly discussed in more detail.

\section{Monodrug Screening on a Microscale Sample}

Based on the microfluidic design, different techniques are employed for monodrug screening. Among them, polymer-based and paper-based microfluidic platforms have been well studied. 
Paper-based microfluidics is a branch of microfluidics consisting of porous and hydrophilic materials like paper that wick fluid by capillary force. Compared to polymerbased microfluidics, the fabrication method of these devices is more straightforward and cost-effective. Most importantly, these platforms can be easily operated without a pump and other bulky, external accessories, making them ideal for point-of-care applications. Accordingly, paper-based microfluidic platforms have been widely used to develop inexpensive, portable, and quick diagnostic medical devices, mainly referred to as microfluidic paper-based analytical devices (microPADs) [29]. However, the absence of continuous medium perfusion limits the wide application of paper devices for cell culture and drug screening applications. Nevertheless, a novel wick-like paper-based microfluidic device has been recently developed to overcome this drawback [30]. This platform is used for medium self-driven perfusion during the three-dimensional cell culture and further anticancer drug screening.

Polymer-based devices are mainly built from polydimethylsiloxane (PDMS) using soft lithography techniques. Some microchips take advantage of concentration gradient generators (CGGs) [23,31,32], while others set drug dosage manually on a microwell platform or automatically by diffusivity of the reagents. Moreover, they can use 2D or 3D cell cultures.

Some of these microfluidic platforms for monodrug screening on a microscale sample are shown in Figure 1. The microwell platform shown in Figure 1a uses a 2D cell culture, and the nutrients/drugs diffuse from microchannels to microwells [33]. In contrast, in Figure $1 \mathrm{~b}$, an alginate $3 \mathrm{D}$ cell culture is injected by a micropillar chip onto a microwell platform [34].A microarray spotter dispensed the drug solutions onto the microwell chip. Figure 1c is a two-layer PDMS-based microfluidic device with an integrated cell culture membrane that can be used for both drug delivery and mechanotransduction [23]. It should be noted that the size of the membrane can be tailored based on the sample size. Figure $1 \mathrm{~d}$ automatically shows generation of drug dosages based on the diffusion process onto a 3D biopsy-derived spheroids microwell platform [35]. Although 2D cell cultures are still used for most research, the 3D cell culture industry is more appropriate, especially in cancer research. In the following, we classified monodrug testing on microscale samples based on cell-culture type (two dimensional or three dimensional).

\subsection{Two-Dimensional Cell Cultures}

Ye et al. described a microfluidic device consisting of multiple drug gradient generators to measure different cellular parameters in anti-cancer drug-induced apoptosis of human liver carcinoma HepG2 cells [36]. This platform consists of eight uniform structure units, and each unit has an upstream CGG and downstream parallel cell culture chambers. Their microscale cell culture arrays allow high-throughput screening in response to different doses of drugs with discrete concentration gradients. They also thoroughly evaluated other cellular responses such as nuclear size and membrane permeability. Wlodkowic et al. reported a PDMS-based cell array consisting of 440 micromechanical traps to screen anti-cancer drugs in real-time [37]. In this kinetic on-chip assay, researchers investigated the staurosporine-induced tumor cell death over human promyelocytic leukaemia (HL60) and histiocytic leukaemia (U937) cell lines. Utilizing this platform realizes high-throughput screening and automated single-cell microarray cytometry with a smaller number of cells and eliminates the need for single-pass flow cytometer measurements.

$\mathrm{Li}$ et al. developed a microfluidic chip to evaluate the cytotoxicity of two oxygendependent anti-cancer drugs (TPZ and Cisplatin) to A549 cells [38]. They tested a single drug dose under different oxygen tensions.

Wong et al. exploited a droplet-based microfluidic device for drug screening on cancer cell lines and cells separated from a human primary tumor [39]. All samples were tested on-chip against four anti-cancer drugs, namely bortezomib, epirubicin, cisplatin, and vorinostat, for five assay conditions based on sample input size and throughput 
requirement. This platform provides a rapid and low-input sample drug screening of potentially all types of cancer.
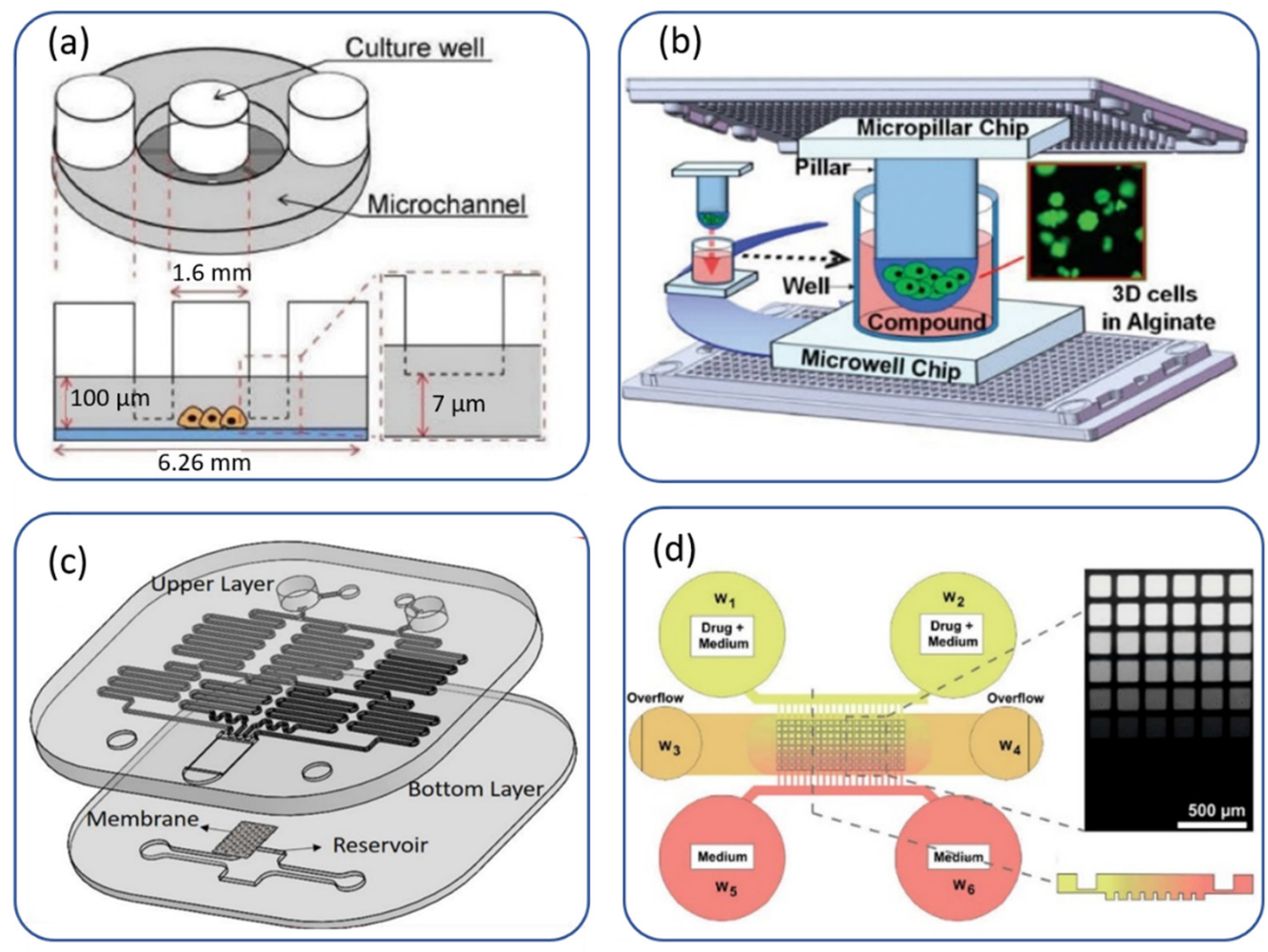

Figure 1. Monodrug screening on a microscale sample: (a) a microwell platform to trap cells in 96-well plates. Reproduced from Ref. [33] under an open access Creative Common CC BY license. (b) Micropillar-microwell platform for alginate 3D cell culture (since the cell-containing micropillar chips lay onto the medium-containing microwell chips, replacing the growth media in this platform is easier than conventional hydrogel 3D cell cultures). Reproduced with permission from Ref. [34]. (c) An integrated microfluidic concentration gradient generator for mechanical stimulation and drug delivery. The device consists of two layers of PDMS with an integrated membrane sandwiched between the two layers. The device can generate four different concentrations of a drug and, at the same time, it can impose the adjustable shear stress and osmotic pressure gradients on the cultured cells. Reproduced from Ref. [23] under an open access Creative Common CC BY license. (d) A diffusion-based gradient generation microwell platform for biopsy-derived spheroids. Reproduced from Ref. [35] under an open access Creative Common CC BY license.

Microwell chips are widely used to trap cells or tissue slices for drug screening. Ma et al. described a micro-gap plate with 96 units arranged in the standard format of a 96-well plate to test the response of breast cancer cell lines (MCF7 and MDA-MB-231) and patient primary samples to two anti-cancer drugs, namely cisplatin and docetaxel [33]. Their presented design consisted of culture wells, micro-gaps, and microchannels. The small height of micro-gaps aided cell conservation during solution exchange.

Wang et al. engineered a multifunctional microfluidic device to estimate the activitytoxicity in a cell model simultaneously [40]. The optimum drug combination with maximum efficacy and minimal toxicity was predicted by adjusting different concentration ratios of three anti-cancer drugs, including dinatin, diosmetin, and cisplatin, on HEK293 cells.

Mitxelena-Iribarren et al. developed a microfluidic platform for nanoparticle-based chemotherapeutic drug screening [41]. They used integrated microstructures in the cell chamber to enhance fluid mixing and drug-cell interaction. Several methotrexate-based treatments were tested over an osteosarcoma cell monolayer. This platform provides a 
powerful tool for simultaneous screening of up to five different drugs and shows that nanoparticles are a promising target therapy for cancer therapy.

\subsection{Three-Dimensional Cell Cultures}

Yu et al. developed a droplet-based microfluidic system for anti-cancer drug screening on alginate beads with entrapped breast tumor cells [42]. Multicellular aggregates create a three-dimensional environment to encapsulate cells for on-chip incubation. The authors tested the drug response of spheroids originated from LCC6/Her-2 breast tumor cells at four concentrations of doxorubicin. Utilizing this platform with the precise positioning of beads, they showed that multicellular resistance is higher than standard monolayer culture.

Dereli-Korkut et al. reported a 3D microenvironment with microcirculation consisting of three PDMS layers to monitor the dynamic responses of potential or clinical anti-cancer drugs (Tarceva, Staurosporine, and TNF- $\alpha$ with cycloheximide) [43]. The bottom layer has microchambers with cancer cells (human ductal breast epithelial tumor cell line (T47D), human non-small cell lung cancer cell line (PC9), and adult human dermal blood microvascular endothelial cells (HMVEC)) encapsulated in a hydrogel, the middle layer is a permeable membrane, and the upper layer has microchannels with seeded endothelial cells. The advantage of this platform over previous microfluidics without a 3D extracellular matrix is that the cells are not in direct contact with the flow, and diffusion is the primary transport mechanism.

Lee et al. manufactured a 3D cell culture micropillar/microwell chip made of poly (styrene-co-maleic anhydride) which is ideally suited for drug testing on hydrogels of primary cancer cells [34]. The therapeutic efficacy of 24 anti-cancer drugs on a U251 brain cancer cell line and three primary brain cancer cells was measured and well correlated with previous in vivo results of a mouse xenograft model with the three primary brain cancer cells.

Ruppen et al. developed a microfluidic chip to form homogeneous spheroids from either cell lines or human primary cells by a sedimentation trap in the microwells [44]. Chemosensitivity tests with cisplatin were performed on primary spheroids cultured as monoculture with epithelial cells and co-culture using epithelial cells and pericytes. The comparison of chemoresistance showed that pericytes protect lung cancer epithelial cells against the chemotherapeutical drug. Thus, this microfluidic device can be used for chemosensitivity tests for personalized medicine.

Chen et al. developed a 3D cell culture microwell chip for anti-cancer drug screening [45]. They used several human cancer cell lines (colon cancer cells HCT116, breast cancer cells T47D, and hepatocellular carcinoma cells HepG2) to form multicellular tumor spheroids for mimicking the ex vivo tumor micro-tissue model for drug screening research. After spheroids formation, two anti-cancer drugs (doxorubicin and paclitaxel) with desired gradient concentrations were injected into the microchannels. They have not reported the specifications of their applied concentration gradient generation. However, their results show that only a three-drug dosage was tested.

Liu et al. developed pneumatic microfluidics for high-throughput anti-cancer drug screening [46]. The advantage of the recyclable microfluidics over a conventional 3D tumor culture system is its cell trapping and its production of similarly sized 3D tumor spheroids from human glioma U251 cells. This single-cell array provides the analysis of different response dynamics and apoptotic signals during chemotherapy with two clinically used anti-cancer drugs (vincristine and bleomycin).

Hong et al. described a paper-based microfluidic with Hela cells, a human epithelial cell line derived from cervical carcinoma cultured with collagen hydrogel as a 3D scaffold and incubated in the device reservoirs [47]. They studied the cell response to a discrete concentration gradient of doxorubicin as a model anti-cancer drug. This hybrid microchip combining paper-based microfluidic and cell culture reservoir is more cost-effective than traditional cell-based bioassays using multi-well plates, and is a promising platform for high-throughput drug screening. 
Fu et al. developed a paper-based microfluidic for anticancer drug screening on MCF-7 and HepG2 cells [30]. This platform was composed of two layers: the upper layer for cell culture and the lower layer for medium self-driven perfusion supply. Moreover, cells were directly seeded in the patterned hydrophilic culture area without hydrogel encapsulation.

Integration of microfluidics and microelectrodes in a 3D tumor microenvironment is a powerful platform to accurately and rapidly monitor the response of cancer cells to different drugs. Pandya et al. engineered a microfluidic platform integrated with the microsensors to measure the electrical response of cancer cells seeded in a 3D gel matrix to a chemotherapeutic drug [48]. This device can delineate three cancer cells, including drug-susceptible, drug-tolerant, and drug-resistant cell, in less than $12 \mathrm{~h}$. They tested five different drug concentrations (carboplatin for B16-F10 and 4T1 cancer cell lines and paclitaxel for prostate cancer cell lines).

Shirure et al. developed a microfluidic platform mimicking drug transport to the tumor cell lines and patient-derived breast cancer organoids through the vascular network [49]. Utilizing this tumor on-a-chip model, different features of tumor progression including cell proliferation, angiogenesis, cell migration, and tumor cell intravasation can be studied. Furthermore, chemo- and anti-angiogenic drugs can be tested on individual tumors for precision medicine. The device has three parallel tissue chambers which are separated by a porous membrane. The central tissue chamber is for the microvasculature and the two side chambers are for loading tumor samples. The fluid flows through the vasculature chamber due to the pressure difference between two fluidic lines.

Mulholland et al. also presented a diffusion-based microfluidic device to screen primary human prostate cancer cells, grown in 3D as a heterogeneous culture from biopsyderived tissue. As proof-of-concept screening, a panel of prostate anti-cancer drugs (cisplatin, docetaxel, and enzalutamide) with eight different dosages were tested on spheroids derived from two patients biopsies [35].

Khoo et al. described a microfluidic device for the expansion of patient-derived circulating tumor cells (CTC) without pre-enrichment procedures [50]. In this platform, CTCs are co-cultured with immune cells on inverted dome-shaped elliptical microwells that provide the formation of CTC clusters within 2 weeks. The addition of inlets in the tree-like gradient generator facilitated the efficient screening of drugs as a combinatorial treatment [51].

\section{Monodrug Screening on a Macroscale Sample}

Chang et al. demonstrated a microfluidic device to study the response of live slice cultures to a range of drug doses in parallel [52]. They confirmed the viability of both the organotypic and GBM xenograft mouse brain slice cultures prior to starting chemotoxicity tests. This PDMS device includes 80 inlet wells connected to downstream microchannels acting as a concentration source or sink. Sources deliver the medium while sinks prevent lateral spread between channels. The delivery channels act as a source, and their adjacent channels act as concentration sinks that prevent lateral spread between delivery channels. A prescribed concentration profile is transported to the tissue slice through the PTFE porous membrane (Figure 2a). Later, Rodrigues et al. manufactured a thermoplastic version of this platform made in PMMA which features less drug absorption. This platform consists of a 40-well plate with an integrated channel network layer for multiplexed drug testing onto GBM xenografts and patient-derived colorectal cancer tumor slices [53].

Astolfi et al. described micro-dissected tumor (MDT) tissues on-chip for personalized therapy [54]. The MDTs were trapped by sedimentation into their respective wells in which they are stable and shielded from excessive shear stress. The advantage of their system is long term survival without the need for continuous perfusion due to the small size of MDTs (below $420 \mu \mathrm{m}$ ). A great advantage of this technique over spheroids on-chip is that it can be used for all types of solid tumors with no dependency on the ability of cells to self-aggregate. 
a)
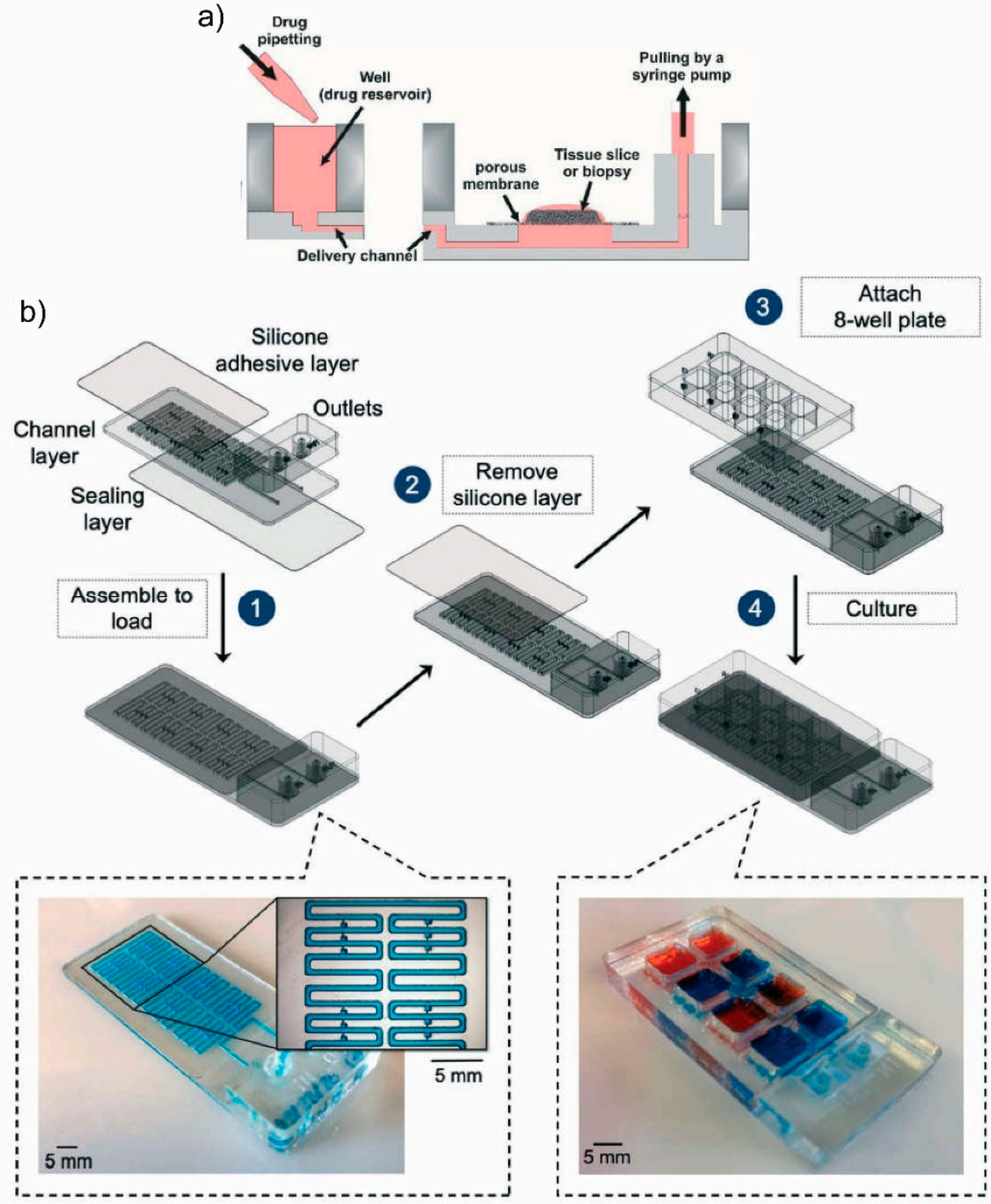

Figure 2. Monodrug screening on a macroscale sample: (a) a microfluidic platform for drug screening on tissue slices cultured on a PTFE porous membrane, reproduced with permission from Ref. [52]. (b) A microfluidic device for drug screening on cuboids with multistage design, with a loading stage (1-2) and a culture stage (3-4). 3D renderings of device components, as well as micrographs of a device ready for loading (filled with blue dye) and of a device ready for culture (wells filled with red and blue dyes). Reproduced with permission from Ref. [55].

Recently, a PMMA microfluidic chip to trap cuboidal-shaped microdissected tissues or "cuboids" was engineered [55]. The similarly sized cuboids (400 $\mu \mathrm{m} \times 400 \mu \mathrm{m} \times 400 \mu \mathrm{m})$, derived from normal mouse liver and human glioma xenograft tumors (U87), were used and cultured within a collagen hydrogel layer on top of the microwell, with an air interface above and culture medium below (Figure 2 b). For proof-of-concept, the cisplatin drug was tested in their 8-well microfluidic device with three different doses.

\section{Combinatorial Drug Screening on a Microscale Sample}

Drug combinations are interesting in cancer treatment for better therapeutic efficacy as compared to a single drug. Different strategies are used for implementing combinatorial drug screening. Concentration gradient generators and valve-based techniques are presented in Figure 3a,b. 


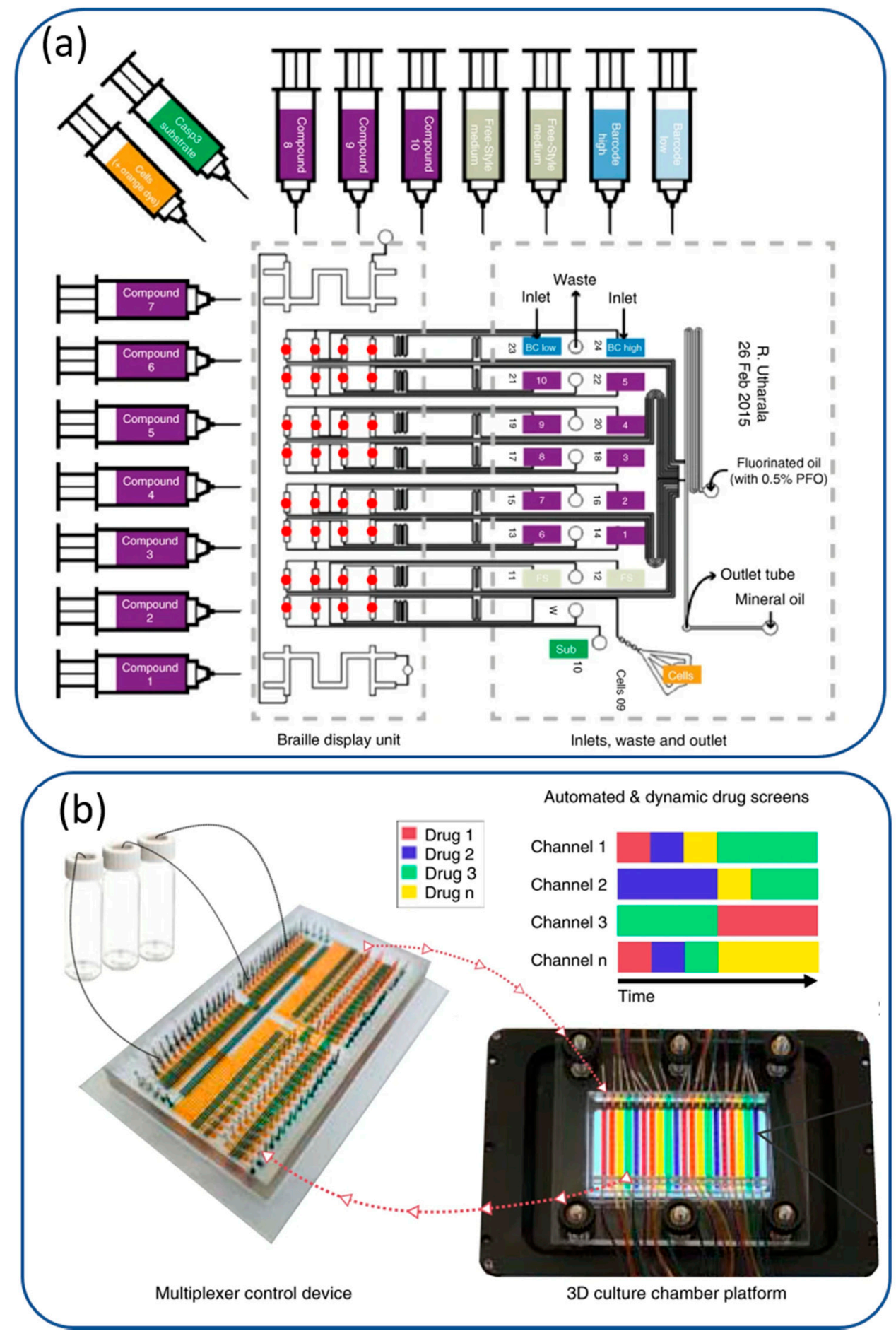

Figure 3. Combinatorial drug screening using (a) a plug-based microfluidic device using braille valves designed on pancreatic cancer biopsies. Reproduced with permission from Ref. [56] under an open access Creative Common CC BY license. (b) a programmable membrane-valve-based microfluidic chip with PDMS-based 3D culture chamber. Reproduced with permission from Ref. [57] under an open access Creative Common CC BY license.

\section{1. $2 D$ Cell Cultures}

In this way, a radial microfluidic concentration gradient generator of two model anticancer drugs was developed [58]. They tested 65 combinatorial compounds over human uterine cervix cancer (HeLa) cells This compact platform with fewer inlets and splitting 
and mixing steps and a large range of predictable concentration gradients is suitable for high-throughput drug screening.

Another combinatorial drug screening microchip generates up to 100 combinatorial concentrations from two input drugs [59]. However, this system has not been applied for screening studies with cells. Similarly, Kim et al. described a programmable microfluidic cell array for combinatorial drug screening on PC3 prostate cancer cells either sequentially or simultaneously [60]. In their device, 64 pair-wise concentration combinations of either doxorubicin or mitoxantrone with TRAIL (TNF-alpha related apoptosis inducing ligand) are tested on cells cultured in 64 independent cell culture chambers. This microfluidic device uses two concentration gradient generators to deliver different concentrations of two drugs to an $8 \times 8$ chamber array with two micropumps for the sequential drug treatment. The advantage of this system is no need for complex multi-layer structures or continuous medium perfusion. However, it should be programmed to individually control the opening and closing of the array of valves, which is a formidable task. This platform has also been tested for curcumin/TRAIL combinational chemotherapy in human prostate cancer PC3 cells [61].

Eduati et al. presented a plug-based microfluidic device for combinatorial drug screening of multiple drugs on pancreatic cancer biopsies [56]. They used braille valves designed to generate up to 1140 plugs per biopsy by 10 different drugs and their pairwise combinations. This is an effective tool for rapid and personalized drug screening on small biopsy samples.

Ding et al. presented a print-to-screen (P2S) platform for high-throughput screening combinatorial chemotherapy [62]. They tested 165 different drug combinations (two or three drugs) of 10 clinically used anti-cancer drugs against ovarian cancer cells (SKOV-3) for a proof-of-concept study. The essential part of their presented P2S platform is the multi-channel microfluidic cartridge with the duty of printing a combinatorial droplet array. The cartridge compromises a pluggable microfluidic chip and an adapter to align the microfluidic chip with the dot-matrix pinhead. The assembly of the cartridge components is in a plug-and-play manner, and the adapter can be modified for other modular designs. Triplicate sets of all drug combinations generated in a $23 \times 23$ array format was spotted onto a gel array on a PDMS substrate. Then, a sheet of the cell embedded gel was laid on the top of the printed drugs array. Their results showed that the highly cytotoxic compounds over the studied cells were combinations of three drugs.

Li et al. fabricated a plug-and-play, drug-on-pillar platform for combination drug screening using a microfluidic pneumatic drug printing platform [63]. They nano formulated chemotherapeutic drugs, which are more stable for storage, shipping, and subsequent rehydration [64]. MDA-MB-231 triple-negative human breast cancer cells were cultured in a 1536-well plate. Then, a $48 \times 32$ printed drug array was laid on top of the cell culture plate. Utilizing this device, a $14 \times 15$ array containing 189 pairwise drug combinations for 7 drugs with 3 concentrations and 21 single-drug groups; eventually, 1260 drug spots with 6 repeats in one 1536-well plate were tested. This system provides a new approach for efficient and convenient combination drug screening.

Shen et al. evaluated the monodrug and combinatorial drug treatments of tumor cell lines (MCF-7 and HepG2) with two anti-cancer drugs (doxorubicin and cisplatin) [65]. They constructed three concentration gradients with a unique microchannel structure in a PDMS-based microfluidic device. Since this gradient generator is flow rate-independent, this device is insensitive to operational conditions and is ideal for evaluating personalized medicine of tumor cells.

\subsection{D Cell Cultures}

Bai et al. developed a PDMS-based microfluidic device by co-culturing carcinoma cells with human umbilical vein endothelial cells (HUVECs) for anti-invasive and anti-metastatic combinatorial drug screening [66]. Fan et al. engineered a hydrogel-based microfluidic chip for glioblastoma multiforme (GBM) brain cancer [67]. They cultured U87 cells to 
form spheroids in microwells and performed combinatorial treatment of pitavastatin and irinotecanin. They found that dual drug administration is more effective than administration of individual drugs. This is a powerful platform for high-throughput screening and prolonged drug release and can be used in the future with small biopsy-derived tissue samples. Fabrication of photo-polymerizable poly(ethylene) glycol diacrylate (PEGDA)based microfluidics is easier than polydimethylsiloxane (PDMS). Moreover, PEGDA blocks protein absorption and better mimics the 3D tumor microenvironment.

Zhang et al. developed a high-throughput pairwise drug-combination screening device for arbitrary numbers of drugs [68]. In this system, a logarithmic concentration gradient is generated between each drug pair. Furthermore, for inlets arrangement, a sudoku puzzle is solved to guarantee the adjacent drug pairs cover all the possible combinations. As a proof-of-concept, 7-drug combinatorial treatments were tested over 1032 cancer spheroids of pancreatic cancer patient-derived xenograft cell lines on this three-layer chip. This study benefits precision medicine with high-throughput screening due to low sample consumption and fast analysis.

Khoo et al. recently evaluated the effect of anti-inflammatory combinatorial treatment of doxorubicin and aspirin on cell lines and patient-derived CTC clusters of breast cancer [69]. This microfluidic device could be a valuable clinical decision-support tool for tumor relapse prevention

Chang et al. developed an automated microfluidic platform based on the platform of Kim et al. [60] using pneumatic valves. The combinatorial treatment of doxorubicin and paclitaxel on a thin-gel 3D cell-culture from MDA-MB-231 and MCF-7 breast cancer cell lines was tested [70]. They assembled two air-controlled channel layers, two drug channel layers, and two porous membrane layers on the top and bottom of a cell culture layer. Thus, the cell culture chamber layer is sandwiched between two layers of porous PDMS membranes.

Schuster et al. [57] developed an automated microfluidic platform for dynamic and combinatorial drug screening of tumor organoids. They cultured organoids from different samples, including MDA-MB-231 cell lines, patient-derived pancreatic tumor, and humanderived colon tissue samples. Utilizing this device, 200 different conditions (i.e., 20 different subsets of 10 individual chambers) can be tested. They evaluated individual, combinatorial, and sequential drug screens of chemotherapeutic drugs and found that the temporally modified treatments are more effective than static ones in vitro.

All the presented drug screening platforms for cancer therapy have been summarized in Table 1.

Table 1. Summarizes the presented drug screening platforms for cancer therapy.

\begin{tabular}{|c|c|c|c|}
\hline \multicolumn{4}{|c|}{ Monodrug Screening on a Microscale Sample } \\
\hline Sample Type & Tested Drugs & Number of Dosages Tested & Ref. \\
\hline Carcinoma (HepG2) cell line & $\begin{array}{l}\text { Daunorubicin, idarubicin, } \\
\text { cisplatin, carboplatin, mitomycin, bleomycin, } \\
\text { and actinomycin D }\end{array}$ & 8 & [36] \\
\hline $\begin{array}{l}\text { Human promyelocytic leukaemia (HL60) and } \\
\text { histiocytic leukaemia (U937) cell lines }\end{array}$ & Staurosporine & 1 & [37] \\
\hline A549 cell line & Tirapazamine and cisplatin & 1 & [38] \\
\hline $\begin{array}{l}\text { Suspended (Jurkat E6.1) and adherent (MDA-MB-231) } \\
\text { cancer cell lines }\end{array}$ & $\begin{array}{l}\text { Bortezomib, epirubicin, cisplatin, and } \\
\text { vorinostat }\end{array}$ & 7 & [39] \\
\hline $\begin{array}{l}\text { Breast cancer cell lines (MCF7 and MDA-MB-231) and } \\
\text { patient primary samples }\end{array}$ & Cisplatin and docetaxel & 4 & {$[33]$} \\
\hline HEK293 cells & Dinatin, diosmetin, and cisplatin & 9 & {$[40]$} \\
\hline U-2 OS osteosarcoma cell line & $\begin{array}{l}\text { Methotrexate-based treatments (free MTX, } \\
\text { MTX loaded lecithin-PVA nanoparticles, } \\
\text { MTX loaded lecithin-Tween } \\
80 \text { nanoparticles) }\end{array}$ & 2 & {$[41]$} \\
\hline
\end{tabular}


Table 1. Cont.

\begin{tabular}{|c|c|c|c|}
\hline \multicolumn{4}{|c|}{ Monodrug Screening on a Microscale Sample } \\
\hline Sample Type & Tested Drugs & Number of Dosages Tested & Ref. \\
\hline 3D spheroids from LCC6/Her-2 breast tumor cells & Doxorubicin & 4 & [42] \\
\hline $\begin{array}{l}\text { 3D hydrogel from human ductal breast epithelial } \\
\text { tumor cell line (T47D), human non-small cell lung } \\
\text { cancer cell line (PC9), and adult human dermal blood } \\
\text { microvascular endothelial cells (HMVEC) }\end{array}$ & $\begin{array}{l}\text { Tarceva, } \\
\text { staurosporine, and TNF- } \alpha \text { with } \\
\text { cycloheximide }\end{array}$ & 1 & [43] \\
\hline $\begin{array}{l}\text { 3D hydrogel from human glioma U251 } \\
\text { cell line and three primary GBM cells }\end{array}$ & 24 different anti-cancer drugs & 6 & [34] \\
\hline $\begin{array}{l}\text { Homogeneous 3D spheroids from either mesothelioma } \\
\text { cell line } \\
\text { (H2052) or epithelial adenocarcinoma primary cells }\end{array}$ & Cisplatin & $\begin{array}{l}\text { Mono-culture: } 10 \\
\text { Co-culture (with primary } \\
\text { pericytes): } 6\end{array}$ & [44] \\
\hline Spheroids from carcinoma (HepG2) cell line & Doxorubicin and paclitaxel & 3 & [45] \\
\hline $\begin{array}{l}\text { Similarly sized 3D tumor spheroids from human } \\
\text { glioma U251 cells }\end{array}$ & Vincristine and bleomycin & 6 & [46] \\
\hline $\begin{array}{l}\text { 3D hydrogel from human epithelial cell line derived } \\
\text { from cervical carcinoma (Hela) }\end{array}$ & Doxorubicin & 5 & [47] \\
\hline $\begin{array}{l}\text { Human breast adenocarcinoma cell line (MCF-7), } \\
\text { hepatocellular carcinoma cell line (HepG2), and } \\
\text { normal human fetal liver cells (L-02) }\end{array}$ & Paclitaxel, doxorubicin, quercetin, and rutin & 6 & [30] \\
\hline $\begin{array}{l}\text { 3D gel matrix from B16-F10 mouse melanoma, } 4 \mathrm{~T} 1 \\
\text { mouse breast cancer and DU } 145 \text { human prostate } \\
\text { cancer cell lines }\end{array}$ & Carboplatin and paclitaxel & 5 & [48] \\
\hline $\begin{array}{l}\text { Cell lines and } \\
\text { patient-derived breast cancer organoids }\end{array}$ & Bevacizumab, TGF $\beta$, and paclitaxel & 4 & [49] \\
\hline $\begin{array}{l}\text { 3D spheroids from primary human } \\
\text { prostate cancer cells }\end{array}$ & Enzalutamide, docetaxel, or cisplatin & 8 & [35] \\
\hline \multicolumn{4}{|c|}{ Monodrug screening on a macroscale sample } \\
\hline Sample Type & Tested Drugs & Number of Dosages Tested & Ref. \\
\hline $\begin{array}{l}\text { Both the organotypic and GBM xenograft mouse brain } \\
\text { slice cultures }\end{array}$ & Staurosporine & 7 & [52] \\
\hline $\begin{array}{l}\text { GBM xenografts and patient-derived colorectal cancer } \\
\text { tumor slices. }\end{array}$ & $\begin{array}{l}\text { 17-AAG, bortezomib, cisplatin, DMSO, } \\
\text { mocetinostat, MLN 2238, and parthenolide }\end{array}$ & 1 & [53] \\
\hline $\begin{array}{l}\text { Micro-dissected tumor (MDT) tissues ( } 4 \text { mouse } \\
\text { xenografts derived from human cancer cell lines, } 3 \\
\text { from ovarian and prostate } \\
\text { cancer patients, and } 1 \text { from a patient with benign } \\
\text { prostatic hyperplasia) }\end{array}$ & Carboplatin & 1 & [54] \\
\hline $\begin{array}{l}\text { Cell lines and } \\
\text { patient-derived breast cancer organoids }\end{array}$ & Bevacizumab, TGF $\beta$, and paclitaxel & 4 & [49] \\
\hline $\begin{array}{l}\text { Uniformly sized cuboids of normal mouse liver and } \\
\text { human glioma xenograft tumors (U87) }\end{array}$ & Cisplatin & 3 & [55] \\
\hline \multicolumn{4}{|c|}{ Combinatorial drug screening on a microscale sample } \\
\hline Sample Type & Tested Drugs & Number of Combinations Tested & Ref. \\
\hline $\begin{array}{c}\text { Human } \\
\text { uterine cervix cancer (HeLa) cells }\end{array}$ & 5-fluorouracil and cyclophosphamide & 65 & [58] \\
\hline PC3 prostate cancer cells (PC3) & $\begin{array}{l}\text { Doxorubicin or mitoxantrone with TRAIL } \\
\text { (TNF-alpha related apoptosis inducing } \\
\text { ligand) either sequentially or simultaneously }\end{array}$ & 64 & [60] \\
\hline Human prostate cancer PC3 cells & Curcumin and TRAIL & 64 & [61] \\
\hline $\begin{array}{l}\text { Two genetically different } \\
\text { pancreatic cancer cell lines, xenograft mouse models, } \\
\text { and human solid tumor-derived cells }\end{array}$ & $\begin{array}{c}10 \text { drugs: } \\
\text { ACHP, AZD6244, Cyt387 GDC0941, gefitinib } \\
\text { MK-2206, PHT-427, gemcitabine, oxaliplatin, } \\
\text { and TNF } \alpha\end{array}$ & 56 & [71] \\
\hline
\end{tabular}


Table 1. Cont.

\begin{tabular}{|c|c|c|c|}
\hline \multicolumn{4}{|c|}{ Monodrug Screening on a Microscale Sample } \\
\hline Sample Type & Tested Drugs & Number of Combinations Tested & Ref. \\
\hline Ovarian cancer cells (SKOV-3) & $\begin{array}{l}\text { Methotrexate, adriamycin hydrochloride, } \\
\text { BCNU, tamoxifen, thalidomide, celecoxib, } \\
\text { actinomycin D, streptonigrin, mitomycin, } \\
\text { and ellipticine }\end{array}$ & $\begin{array}{l}165 \\
\text { (2 or } 3 \text { drugs) } \\
\text { Triplicate }\end{array}$ & [62] \\
\hline MDA-MB-231 triple negative human breast cancer cells & $\begin{array}{l}\text { Doxorubicin, nilotinib, olaparib, capsaicin, } \\
\text { tamoxifen, cisplatin, and tretinoin }\end{array}$ & $\begin{array}{c}210 \\
\text { (1 or } 2 \text { drugs) } \\
\text { sextuple }\end{array}$ & [63] \\
\hline Tumor cell lines (MCF-7 and HepG2) & Doxorubicin and cisplatin & 3 & [65] \\
\hline $\begin{array}{l}\text { 3D hydrogel aggregates of carcinoma cell (A549 and } \\
\text { T24) co-cultured with human umbilical vein } \\
\text { endothelial monolayer cells (HUVECs) }\end{array}$ & MK-2206, AZD-0530, A83-01, and CI-1033 & 12 & [66] \\
\hline $\begin{array}{l}\text { 3D spheroids from glioblastoma multiforme (GBM) } \\
\text { brain cancer (U87) cells }\end{array}$ & Pitavastatin and irinotecanin & 8 & [67] \\
\hline $\begin{array}{l}\text { Spheroids of pancreatic cancer cell lines (MIA PaCa-2) } \\
\text { and patient-derived xenograft cells }\end{array}$ & $\begin{array}{l}7 \text { drugs: cisplatin, docetaxel, doxorubicin, } \\
\text { gemcitabine, irinotecan, } \\
\text { oxaliplatin, and 5-FU }\end{array}$ & 28 & [68] \\
\hline $\begin{array}{c}\text { Cell lines and patient-derived CTC clusters of } \\
\text { breast cancer }\end{array}$ & Doxorubicin and aspirin & 8 & [69] \\
\hline $\begin{array}{l}\text { Thin-gel 3D cell-culture from MDA-MB-231 and } \\
\text { MCF-7 breast cancer cell lines }\end{array}$ & Doxorubicin and paclitaxel & 64 & [70] \\
\hline $\begin{array}{c}\text { 3D cell structures from a cancer cell line } \\
\text { (MDA-MB-231) grown into aggregates, pancreatic } \\
\text { tumor, organoids from patient-derived samples, and } \\
\text { colon organoids from human-derived normal colon } \\
\text { tissue samples }\end{array}$ & $\begin{array}{l}\text { Gemcitabine, paclitaxel, } \\
\text { fluorouracil (5-FU), docetaxel, CPT11, } \\
\text { oxliplatin, and cisplatin }\end{array}$ & 5 combinatorial for 3 patients & [57] \\
\hline
\end{tabular}

\section{Limitations of Current Microfluidic Platforms for Drug Screening}

Although microfluidic devices can be considered as a next generation platform for anti-cancer drug screening and personalized medicine, these devices have a number of bench-to-bedside translational challenges that need to be addressed. Broadly speaking, several preclinical aspects such as repeatability, safety, formulation, dose, the timing of drug delivery, and most importantly, pharmacokinetics, must be satisfied before the results of an in vitro drug delivery platform can move on to human trials [72]. In terms of safety, while most microfluidic materials are biocompatible, there are several challenges associated with choosing the right microfluidic material. In other words, microfabrication technology hugely affects the selection of a microfluidic material. For instance, PDMS is the material of choice for the soft lithography process. While PDMS is biocompatible, transparent, and oxygen permeable, leaching of uncross-linked oligomers from PDMS may adversely affect the inherent cell's behavior [73]. Moreover, due to the scalability issues associated with PDMS casting, PDMS-based microfluidic devices are not suitable for large-scale commercialized applications. Accordingly, shifting from PDMS to thermoplastic materials, especially cyclic olefin copolymer, and adopting the related microfabrication processes in academia can rectify this issue [74]. With the advent of 3D bioprinting technologies, biofabricating a viable sample at the organ level has been feasible [75]. These platforms can rectify cell viability for extended durations by including vascular networks on the bioprinted organ to facilitate the exchange of the required oxygen and nutrients and the removal of the biological wastes. There is still a huge space for incorporating bioprinted vascularized organs for drug screening applications that needs to be explored.

Another translational challenge of a microfluidic platform for drug screening is the level of user-friendliness and external accessories they require for operation. While the use on-chip micropumps and microvalves has been developed for most lab-on-a-chip applications, using these integrated components for high-throughput drug screening is still unexplored. On the other hand, adding these integrated components may overcom- 
plicate the platform and decrease its user-friendly level, thus inhibiting its acceptance in clinical settings.

Another important challenge of in-vitro microfluidic platforms is the accurate study of the absorption, distribution, metabolism, and excretion, commonly known as pharmacokinetics. To this aim, the effect of a drug on various organs, including the lungs, liver, kidneys, and gut, should be studied simultaneously. In the context of anti-cancer drug screening, multi-organs-on-a-chip platforms should be coupled with tumor-on-a-chip ones to better study the pharmacokinetics and related side effects of the drug. As such, a combination of these platforms with concentration gradient generators for high-throughput multi-drug screening can open new avenues in this field.

In the context of personalized medicine, the microfluidic devices should be compatible with patient-derived samples. According to the limitation of current microfluidic platforms, there is a lack of combinatorial drug screening on macroscale samples, e.g., a patient's tissue sample obtained through surgical biopsy. A continuous gradient is generated on a macroscale sample in a few of the current microfluidic devices. In this way, the recent microfluidic device developed by Rismanian et al. [76], with the capability of delivering two different reagents simultaneously on a microdissected tissue sample, is a promising platform as shown in Figure 4. Utilizing the presented microfluidic device, continuous linear gradients of two reagents could be generated along with the two different directions on a millimeter-sized sample (sample length and width). So, all possible combinations of two drugs would be distributed on the sample surface. Future works could focus on drug screening on the cancer tissue samples loaded in this microfluidic device.

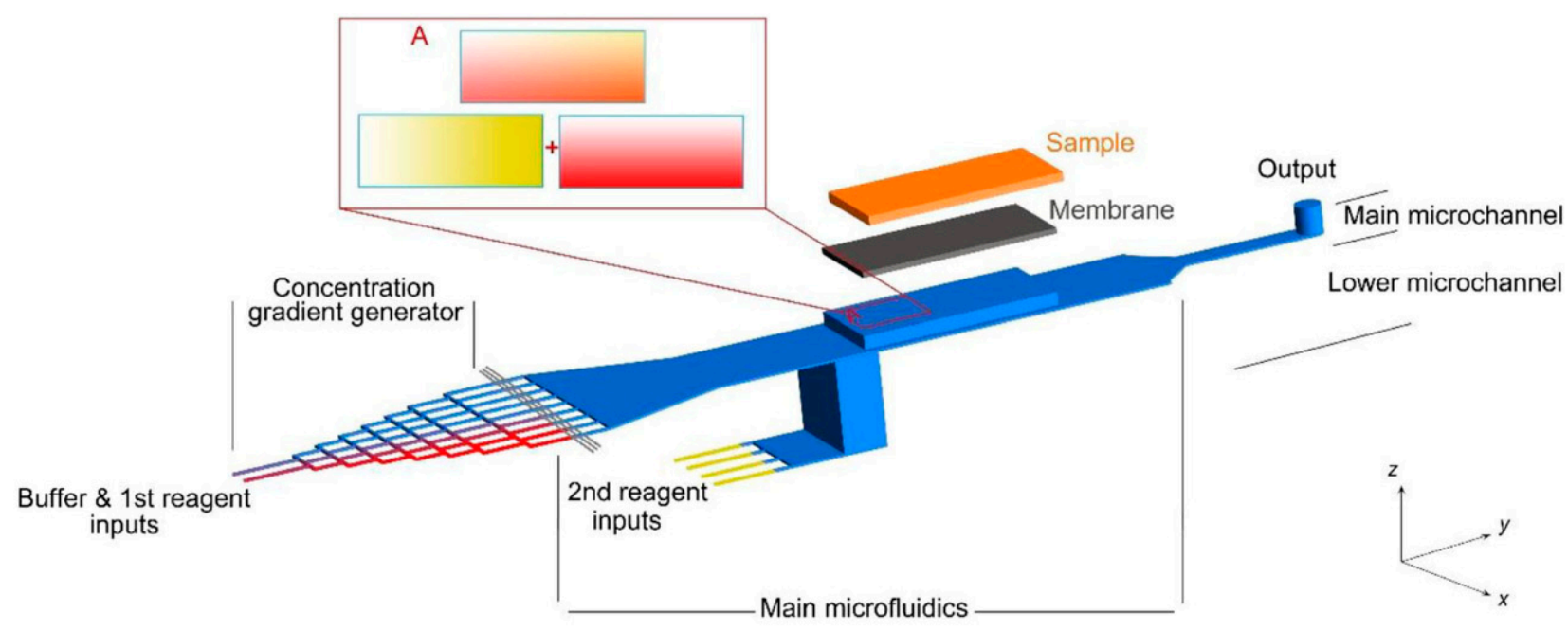

Figure 4. A microfluidic platform for delivering continuous concentration gradients of two different reagents on a tissue sample simultaneously. Reproduced with permission from Ref. [76].

\section{Conclusions and Future Perspectives}

The main objective of this review was to provide a guideline to select the appropriate microfluidic drug screening chips based on the available sample size. Accordingly, this study classified the current microfluidic platforms for drug screening into three categories based on sample size and the mode of drug screening (i.e., combinatorial or monodrug). Specifically, the following microfluidic platforms for drug screening were critically overviewed: (i) monodrug screening on a microscale sample, (ii) monodrug screening on a macroscale sample, and (iii) combinatorial drug screening on a microscale sample (Table 1).

Moreover, we briefly discussed the limitations of current microfluidic platforms for anti-cancer drug screening and presented some possible solutions to tackle these problems. In particular, the microfluidic material, microfabrication techniques, and pharmacokinetics 
of drugs should be carefully considered in the research and development (R\&D) phase before these platforms can be translated to real clinical settings. To this aim, more advanced multi-organs-on-a-chip platforms should be integrated with the tumor-on-a-chip system, while the user-friendly level and clinical acceptance of such complex platforms should be considered in the R\&D phase. In addition, more microfluidic drug screening platforms studying the continuous gradient of multi-drugs of a macroscale sample (i.e., patient's tissue) need to be developed. Finally, with the advent of 3D bioprinting technologies, all the evaluated platforms can be 3D printed with a biocompatible material and can be further investigated for drug screening. Most importantly, the 3D bioprinting technique can realize drug screening on vascularized organs and revolutionize this field.

Author Contributions: Conceptualization, N.K. and M.M.; methodology, M.M.; software, M.M.; validation, M.M., M.R. and N.K.; formal analysis, N.K.; investigation, M.M.; resources, M.M. and H.J.; data curation, M.M.; writing—original draft preparation, M.M. and N.K.; writing-review and editing, M.M., M.R. and H.J.; visualization, M.M. and M.R.; supervision, N.K.; project administration, H.J. and N.K. All authors have read and agreed to the published version of the manuscript.

Funding: This research received no external funding.

Institutional Review Board Statement: Not applicable.

Informed Consent Statement: Not applicable.

Conflicts of Interest: The authors declare no conflict of interest.

\section{References}

1. Wlodkowic, D.; Cooper, J.M. Tumors on chips: Oncology meets microfluidics. Curr. Opin. Chem. Biol. 2010, $14,556-567$. [CrossRef]

2. Boussommier-Calleja, A.; Li, R.; Chen, M.B.; Wong, S.C.; Kamm, R.D. Microfluidics: A new tool for modeling cancer-immune interactions. Trends Cancer 2016, 2, 6-19. [CrossRef]

3. Daley, W.P.; Peters, S.B.; Larsen, M. Extracellular matrix dynamics in development and regenerative medicine. J. Cell Sci. 2008, 121, 255-264. [CrossRef]

4. Santo, V.E.; Rebelo, S.P.; Estrada, M.F.; Alves, P.M.; Boghaert, E.; Brito, C. Drug screening in 3D in vitro tumor models: Overcoming current pitfalls of efficacy read-outs. Biotechnol. J. 2017, 12, 1600505. [CrossRef]

5. Zanoni, M.; Piccinini, F.; Arienti, C.; Zamagni, A.; Santi, S.; Polico, R.; Bevilacqua, A.; Tesei, A. 3D tumor spheroid models for in vitro therapeutic screening: A systematic approach to enhance the biological relevance of data obtained. Sci. Rep. 2016, 6, 19103. [CrossRef]

6. Brancato, V.; Oliveira, J.M.; Correlo, V.M.; Reis, R.L.; Kundu, S.C. Could 3D models of cancer enhance drug screening? Biomaterials 2020, 232, 119744. [CrossRef]

7. Datta, P.; Dey, M.; Ataie, Z.; Unutmaz, D.; Ozbolat, I.T. 3D bioprinting for reconstituting the cancer microenvironment. NPJ Precis. Oncol. 2020, 4, 18. [CrossRef]

8. Abbasi, N.; Hamlet, S.; Love, R.M.; Nguyen, N.-T. Porous scaffolds for bone regeneration. J. Sci. Adv. Mater. Devices 2020, 5, 1-9. [CrossRef]

9. Li, W.; Khan, M.; Mao, S.; Feng, S.; Lin, J.-M. Advances in tumor-endothelial cells co-culture and interaction on microfluidics. J. Pharm. Anal. 2018, 8, 210-218. [CrossRef] [PubMed]

10. Shang, M.; Soon, R.H.; Lim, C.T.; Khoo, B.L.; Han, J. Microfluidic modelling of the tumor microenvironment for anti-cancer drug development. Lab Chip 2019, 19, 369-386. [CrossRef] [PubMed]

11. Du, G.; Fang, Q.; den Toonder, J.M. Microfluidics for cell-based high throughput screening platforms-A review. Anal. Chim. Acta 2016, 903, 36-50. [CrossRef]

12. Liu, X.; Zheng, W.; Jiang, X. Cell-Based Assays on Microfluidics for Drug Screening. ACS Sens. 2019, 4, 1465-1475. [CrossRef]

13. Al-Lazikani, B.; Banerji, U.; Workman, P. Combinatorial drug therapy for cancer in the post-genomic era. Nat. Biotechnol. 2012, 30, 679-692. [CrossRef]

14. Fisher, R.; Pusztai, L.; Swanton, C. Cancer heterogeneity: Implications for targeted therapeutics. Br. J. Cancer 2013, 108, 479-485. [CrossRef]

15. Masui, K.; Harachi, M.; Cavenee, W.K.; Mischel, P.S.; Shibata, N. Codependency of Metabolism and Epigenetics Drives Cancer Progression: A Review. Acta Histochem. Cytochem. 2020, 53, 1-10. [CrossRef]

16. Zimmermann, G.R.; Lehár, J.; Keith, C.T. Multi-target therapeutics: When the whole is greater than the sum of the parts. Drug Discov. Today 2007, 12, 34-42. [CrossRef]

17. Holohan, C.; Van Schaeybroeck, S.; Longley, D.B.; Johnston, P.G. Cancer drug resistance: An evolving paradigm. Nat. Rev. Cancer 2013, 13, 714-726. [CrossRef] 
18. Macarron, R.; Banks, M.N.; Bojanic, D.; Burns, D.J.; Cirovic, D.A.; Garyantes, T.; Green, D.V.; Hertzberg, R.P.; Janzen, W.P.; Paslay, J.W. Impact of high-throughput screening in biomedical research. Nat. Rev. Drug Discov. 2011, 10, 188-195. [CrossRef]

19. Bandara, T.; Nguyen, N.-T.; Rosengarten, G. Slug flow heat transfer without phase change in microchannels: A review. Chem. Eng. Sci. 2015, 126, 283-295. [CrossRef]

20. Barisam, M.; Saidi, M.S.; Kashaninejad, N.; Vadivelu, R.; Nguyen, N.-T. Numerical Simulation of the Behavior of Toroidal and Spheroidal Multicellular Aggregates in Microfluidic Devices with Microwell and U-Shaped Barrier. Micromachines 2017, 8, 358. [CrossRef]

21. Tajik, P.; Saidi, M.S.; Kashaninejad, N.; Nguyen, N.-T. Simple, Cost-Effective, and Continuous 3D Dielectrophoretic Microchip for Concentration and Separation of Bioparticles. Ind. Eng. Chem. Res. 2020, 59, 3772-3783. [CrossRef]

22. Vadivelu, R.; Kashaninejad, N.; Sreejith, K.R.; Bhattacharjee, R.; Cock, I.; Nguyen, N.-T. Cryoprotectant-Free Freezing of Cells Using Liquid Marbles Filled with Hydrogel. ACS Appl. Mater. Interfaces 2018, 10, 43439-43449. [CrossRef]

23. Yahyazadeh Shourabi, A.; Kashaninejad, N.; Saidi, M.S. An integrated microfluidic concentration gradient generator for mechanical stimulation and drug delivery. J. Sci. Adv. Mater. Devices 2021, 6, 280-290. [CrossRef]

24. Dhiman, N.; Kingshott, P.; Sumer, H.; Sharma, C.S.; Rath, S.N. On-chip anticancer drug screening-Recent progress in microfluidic platforms to address challenges in chemotherapy. Biosens. Bioelectron. 2019, 137, 236-254. [CrossRef]

25. Valente, K.P.; Khetani, S.; Kolahchi, A.R.; Sanati-Nezhad, A.; Suleman, A.; Akbari, M. Microfluidic technologies for anticancer drug studies. Drug Discov. Today 2017, 22, 1654-1670. [CrossRef]

26. Fung, W.-T.; Beyzavi, A.; Abgrall, P.; Nguyen, N.-T.; Li, H.-Y. Microfluidic platform for controlling the differentiation of embryoid bodies. Lab Chip 2009, 9, 2591-2595. [CrossRef] [PubMed]

27. Russano, M.; Napolitano, A.; Ribelli, G.; Iuliani, M.; Simonetti, S.; Citarella, F.; Pantano, F.; Dell'Aquila, E.; Anesi, C.; Silvestris, N.; et al. Liquid biopsy and tumor heterogeneity in metastatic solid tumors: The potentiality of blood samples. J. Exp. Clin. Cancer Res. 2020, 39, 95. [CrossRef] [PubMed]

28. Rostami, P.; Kashaninejad, N.; Moshksayan, K.; Saidi, M.S.; Firoozabadi, B.; Nguyen, N.-T. Novel approaches in cancer management with circulating tumor cell clusters. J. Sci. Adv. Mater. Devices 2019, 4, 1-18. [CrossRef]

29. Nishat, S.; Jafry, A.T.; Martinez, A.W.; Awan, F.R. Paper-based microfluidics: Simplified fabrication and assay methods. Sens. Actuators B Chem. 2021, 336, 129681. [CrossRef]

30. Fu, S.-X.; Zuo, P.; Ye, B.-C. A Novel Wick-Like Paper-Based Microfluidic Device for 3D Cell Culture and Anti-Cancer Drugs Screening. Biotechnol. J. 2021, 16, 2000126. [CrossRef] [PubMed]

31. Rismanian, M.; Saidi, M.S.; Kashaninejad, N. A new non-dimensional parameter to obtain the minimum mixing length in tree-like concentration gradient generators. Chem. Eng. Sci. 2019, 195, 120-126. [CrossRef]

32. Ebadi, M.; Moshksayan, K.; Kashaninejad, N.; Saidi, M.S.; Nguyen, N.-T. A tool for designing tree-like concentration gradient generators for lab-on-a-chip applications. Chem. Eng. Sci. 2020, 212, 115339. [CrossRef]

33. Ma, W.Y.; Hsiung, L.C.; Wang, C.H.; Chiang, C.L.; Lin, C.H.; Huang, C.S.; Wo, A.M. A novel 96well-formatted micro-gap plate enabling drug response profiling on primary tumour samples. Sci. Rep. 2015, 5, 9656. [CrossRef] [PubMed]

34. Lee, D.W.; Choi, Y.S.; Seo, Y.J.; Lee, M.Y.; Jeon, S.Y.; Ku, B.; Kim, S.; Yi, S.H.; Nam, D.H. High-throughput screening (HTS) of anticancer drug efficacy on a micropillar/microwell chip platform. Anal. Chem. 2014, 86, 535-542. [CrossRef]

35. Mulholland, T.; McAllister, M.; Patek, S.; Flint, D.; Underwood, M.; Sim, A.; Edwards, J.; Zagnoni, M. Drug screening of biopsy-derived spheroids using a self-generated microfluidic concentration gradient. Sci. Rep. 2018, 8, 14672. [CrossRef]

36. Ye, N.; Qin, J.; Shi, W.; Liu, X.; Lin, B. Cell-based high content screening using an integrated microfluidic device. Lab Chip 2007, 7, 1696-1704. [CrossRef]

37. Wlodkowic, D.; Faley, S.; Zagnoni, M.; Wikswo, J.P.; Cooper, J.M. Microfluidic single-cell array cytometry for the analysis of tumor apoptosis. Anal. Chem. 2009, 81, 5517-5523. [CrossRef]

38. Li, Y.; Li, L.; Liu, Z.; Ding, M.; Luo, G.; Liang, Q. A microfluidic chip of multiple-channel array with various oxygen tensions for drug screening. Microfluid. Nanofluidics 2016, 20,1-9. [CrossRef]

39. Wong, A.H.; Li, H.; Jia, Y.; Mak, P.I.; Martins, R.; Liu, Y.; Vong, C.M.; Wong, H.C.; Wong, P.K.; Wang, H.; et al. Drug screening of cancer cell lines and human primary tumors using droplet microfluidics. Sci. Rep. 2017, 7, 9109. [CrossRef]

40. Wang, H.; Li, T.; Bao, Y.; Wang, S.; Meng, X. A multifunctional integrated simultaneously online screening microfluidic biochip for the examination of "efficacy-toxicity" and compatibility of medicine. Chin. Chem. Lett. 2019, 30, 403-405. [CrossRef]

41. Mitxelena-Iribarren, O.; Zabalo, J.; Arana, S.; Mujika, M. Improved microfluidic platform for simultaneous multiple drug screening towards personalized treatment. Biosens. Bioelectron. 2019, 123, 237-243. [CrossRef]

42. Yu, L.; Chen, M.C.; Cheung, K.C. Droplet-based microfluidic system for multicellular tumor spheroid formation and anticancer drug testing. Lab Chip 2010, 10, 2424-2432. [CrossRef] [PubMed]

43. Dereli-Korkut, Z.; Akaydin, H.D.; Ahmed, A.H.; Jiang, X.; Wang, S. Three dimensional microfluidic cell arrays for ex vivo drug screening with mimicked vascular flow. Anal. Chem. 2014, 86, 2997-3004. [CrossRef] [PubMed]

44. Ruppen, J.; Wildhaber, F.D.; Strub, C.; Hall, S.R.; Schmid, R.A.; Geiser, T.; Guenat, O.T. Towards personalized medicine: Chemosensitivity assays of patient lung cancer cell spheroids in a perfused microfluidic platform. Lab Chip 2015, 15, 3076-3085. [CrossRef] [PubMed]

45. Chen, Y.; Gao, D.; Liu, H.; Lin, S.; Jiang, Y. Drug cytotoxicity and signaling pathway analysis with three-dimensional tumor spheroids in a microwell-based microfluidic chip for drug screening. Anal. Chim. Acta 2015, 898, 85-92. [CrossRef] [PubMed] 
46. Liu, W.; Xu, J.; Li, T.; Zhao, L.; Ma, C.; Shen, S.; Wang, J. Monitoring Tumor Response to Anticancer Drugs Using Stable Three-Dimensional Culture in a Recyclable Microfluidic Platform. Anal. Chem. 2015, 87, 9752-9760. [CrossRef]

47. Hong, B.; Xue, P.; Wu, Y.; Bao, J.; Chuah, Y.J.; Kang, Y. A concentration gradient generator on a paper-based microfluidic chip coupled with cell culture microarray for high-throughput drug screening. Biomed. Microdevices 2016, 18, 21. [CrossRef]

48. Pandya, H.J.; Dhingra, K.; Prabhakar, D.; Chandrasekar, V.; Natarajan, S.K.; Vasan, A.S.; Kulkarni, A.; Shafiee, H. A microfluidic platform for drug screening in a 3D cancer microenvironment. Biosens. Bioelectron. 2017, 94, 632-642. [CrossRef]

49. Shirure, V.S.; Bi, Y.; Curtis, M.B.; Lezia, A.; Goedegebuure, M.M.; Goedegebuure, S.P.; Aft, R.; Fields, R.C.; George, S.C. Tumor-ona-chip platform to investigate progression and drug sensitivity in cell lines and patient-derived organoids. Lab Chip 2018, 18, 3687-3702. [CrossRef]

50. Khoo, B.L.; Grenci, G.; Lim, Y.B.; Lee, S.C.; Han, J.; Lim, C.T. Expansion of patient-derived circulating tumor cells from liquid biopsies using a CTC microfluidic culture device. Nat. Protoc. 2018, 13, 34-58. [CrossRef]

51. Khoo, B.L.; Grenci, G.; Jing, T.; Lim, Y.B.; Lee, S.C.; Thiery, J.P.; Han, J.; Lim, C.T. Liquid biopsy and therapeutic response: Circulating tumor cell cultures for evaluation of anticancer treatment. Sci. Adv. 2016, 2, e1600274. [CrossRef] [PubMed]

52. Chang, T.C.; Mikheev, A.M.; Huynh, W.; Monnat, R.J.; Rostomily, R.C.; Folch, A. Parallel microfluidic chemosensitivity testing on individual slice cultures. Lab Chip 2014, 14, 4540-4551. [CrossRef] [PubMed]

53. Rodriguez, A.D.; Horowitz, L.F.; Castro, K.; Kenerson, H.; Bhattacharjee, N.; Gandhe, G.; Raman, A.; Monnat, R.J.; Yeung, R.; Rostomily, R.C.; et al. A microfluidic platform for functional testing of cancer drugs on intact tumor slices. Lab Chip 2020, 20, 1658-1675. [CrossRef] [PubMed]

54. Astolfi, M.; Péant, B.; Lateef, M.A.; Rousset, N.; Kendall-Dupont, J.; Carmona, E.; Monet, F.; Saad, F.; Provencher, D.; Mes-Masson, A.M.; et al. Micro-dissected tumor tissues on chip: An ex vivo method for drug testing and personalized therapy. Lab Chip 2016, 16, 312-325. [CrossRef]

55. Horowitz, L.F.; Rodriguez, A.D.; Au-Yeung, A.; Bishop, K.W.; Barner, L.A.; Mishra, G.; Raman, A.; Delgado, P.; Liu, J.T.C.; Gujral, T.S.; et al. Microdissected "cuboids" for microfluidic drug testing of intact tissues. Lab Chip 2021, 21, 122-142. [CrossRef] [PubMed]

56. Eduati, F.; Utharala, R.; Madhavan, D.; Neumann, U.P.; Longerich, T.; Cramer, T.; Saez-Rodriguez, J.; Merten, C.A. A microfluidics platform for combinatorial drug screening on cancer biopsies. Nat. Commun. 2018, 9, 2434. [CrossRef] [PubMed]

57. Schuster, B.; Junkin, M.; Kashaf, S.S.; Romero-Calvo, I.; Kirby, K.; Matthews, J.; Weber, C.R.; Rzhetsky, A.; White, K.P.; Tay, S. Automated microfluidic platform for dynamic and combinatorial drug screening of tumor organoids. Nat. Commun. 2020, 11, 5271. [CrossRef] [PubMed]

58. Yang, C.-G.; Wu, Y.-F.; Xu, Z.-R.; Wang, J.-H. A radial microfluidic concentration gradient generator with high-density channels for cell apoptosis assay. Lab Chip 2011, 11, 3305-3312. [CrossRef]

59. Jang, Y.-H.; Hancock, M.J.; Kim, S.B.; Selimović, Š.; Sim, W.Y.; Bae, H.; Khademhosseini, A. An integrated microfluidic device for two-dimensional combinatorial dilution. Lab Chip 2011, 11, 3277-3286. [CrossRef]

60. Kim, J.; Taylor, D.; Agrawal, N.; Wang, H.; Kim, H.; Han, A.; Rege, K.; Jayaraman, A. A programmable microfluidic cell array for combinatorial drug screening. Lab Chip 2012, 12, 1813-1822. [CrossRef]

61. An, D.; Kim, K.; Kim, J. Microfluidic System Based High Throughput Drug Screening System for Curcumin/TRAIL Combinational Chemotherapy in Human Prostate Cancer PC3 Cells. Biomol. Ther. 2014, 22, 355-362. [CrossRef] [PubMed]

62. Ding, Y.; Li, J.; Xiao, W.; Xiao, K.; Lee, J.; Bhardwaj, U.; Zhu, Z.; Digiglio, P.; Yang, G.; Lam, K.S.; et al. Microfluidic-Enabled Print-to-Screen Platform for High-Throughput Screening of Combinatorial Chemotherapy. Anal. Chem. 2015, 87, 10166-10171. [CrossRef] [PubMed]

63. Li, J.; Tan, W.; Xiao, W.; Carney, R.P.; Men, Y.; Li, Y.; Quon, G.; Ajena, Y.; Lam, K.S.; Pan, T. A Plug-and-Play, Drug-on-Pillar Platform for Combination Drug Screening Implemented by Microfluidic Adaptive Printing. Anal. Chem. 2018, 90, 13969-13977. [CrossRef]

64. Li, Y.; Xiao, K.; Luo, J.; Xiao, W.; Lee, J.S.; Gonik, A.M.; Kato, J.; Dong, T.A.; Lam, K.S. Well-defined, reversible disulfide cross-linked micelles for on-demand paclitaxel delivery. Biomaterials 2011, 32, 6633-6645. [CrossRef]

65. Shen, S.; Zhang, X.; Zhang, F.; Wang, D.; Long, D.; Niu, Y. Three-gradient constructions in a flow-rate insensitive microfluidic system for drug screening towards personalized treatment. Talanta 2020, 208, 120477. [CrossRef]

66. Bai, J.; Tu, T.Y.; Kim, C.; Thiery, J.P.; Kamm, R.D. Identification of drugs as single agents or in combination to prevent carcinoma dissemination in a microfluidic 3D environment. Oncotarget 2015, 6, 36603-36614. [CrossRef]

67. Fan, Y.; Nguyen, D.T.; Akay, Y.; Xu, F.; Akay, M. Engineering a Brain Cancer Chip for High-throughput Drug Screening. Sci. Rep. 2016, 6, 25062. [CrossRef]

68. Zhang, Z.; Chen, Y.-C.; Urs, S.; Chen, L.; Simeone, D.M.; Yoon, E. Scalable Multiplexed Drug-Combination Screening Platforms Using 3D Microtumor Model for Precision Medicine. Small 2018, 14, 1703617. [CrossRef]

69. Khoo, B.L.; Grenci, G.; Lim, J.S.Y.; Lim, Y.P.; Fong, J.; Yeap, W.H.; Bin Lim, S.; Chua, S.L.; Wong, S.C.; Yap, Y.S.; et al. Low-dose anti-inflammatory combinatorial therapy reduced cancer stem cell formation in patient-derived preclinical models for tumour relapse prevention. Br. J. Cancer 2019, 120, 407-423. [CrossRef]

70. Chang, H.C.; Lin, C.H.; Juang, D.; Wu, H.W.; Lee, C.Y.; Chen, C.; Hsu, C.H. Multilayer architecture microfluidic network array for combinatorial drug testing on 3D-cultured cells. Biofabrication 2019, 11, 035024. [CrossRef] 
71. Eduati, F.; Mangravite, L.M.; Wang, T.; Tang, H.; Bare, J.C.; Huang, R.; Norman, T.; Kellen, M.; Menden, M.P.; Yang, J. Prediction of human population responses to toxic compounds by a collaborative competition. Nat. Biotechnol. 2015, 33, 933-940. [CrossRef]

72. Steeves, J.D. Chapter 11-Bench to bedside: Challenges of clinical translation. In Progress in Brain Research; Dancause, N., Nadeau, S., Rossignol, S., Eds.; Elsevier: Amsterdam, The Netherlands, 2015; Volume 218, pp. 227-239.

73. Carter, S.-S.D.; Atif, A.-R.; Kadekar, S.; Lanekoff, I.; Engqvist, H.; Varghese, O.P.; Tenje, M.; Mestres, G. PDMS leaching and its implications for on-chip studies focusing on bone regeneration applications. Organs Chip 2020, 2, 100004. [CrossRef]

74. Liu, Z.; Han, X.; Qin, L. Recent Progress of Microfluidics in Translational Applications. Adv. Healthc. Mater. 2016, 5, 871-888. [CrossRef]

75. Chen, E.P.; Toksoy, Z.; Davis, B.A.; Geibel, J.P. 3D Bioprinting of Vascularized Tissues for in vitro and in vivo Applications. Front. Bioeng. Biotechnol. 2021, 9, 664188. [CrossRef]

76. Rismanian, M.; Saidi, M.S.; Kashaninejad, N. A microfluidic concentration gradient generator for simultaneous delivery of two reagents on a millimeter-sized sample. J. Flow Chem. 2020, 10, 615-625. [CrossRef] 